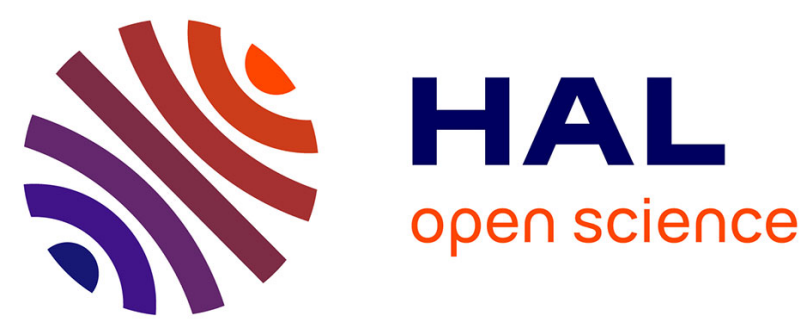

\title{
STRUCTURE DES PHASES PRÉSENTES DANS LES SYSTĖMES LIPIDE-EAU
}

V. Luzzati, T. Gulik-Krzywicki, A. Tardieu

\section{To cite this version:}

V. Luzzati, T. Gulik-Krzywicki, A. Tardieu. STRUCTURE DES PHASES PRÉSENTES DANS LES SYSTĖMES LIPIDE-EAU. Journal de Physique Colloques, 1969, 30 (C4), pp.C4-74-C4-75. 10.1051/jphyscol:1969419 . jpa-00213721

\section{HAL Id: jpa-00213721 https://hal.science/jpa-00213721}

Submitted on 1 Jan 1969

HAL is a multi-disciplinary open access archive for the deposit and dissemination of scientific research documents, whether they are published or not. The documents may come from teaching and research institutions in France or abroad, or from public or private research centers.
L'archive ouverte pluridisciplinaire HAL, est destinée au dépôt et à la diffusion de documents scientifiques de niveau recherche, publiés ou non, émanant des établissements d'enseignement et de recherche français ou étrangers, des laboratoires publics ou privés. 


\title{
POLYMẼRES AMPHIPATHIQUES
}

\author{
A. SKOULIOS
}

Centre de Recherches sur les Macromolécules de Strasbourg

Résumé. - Certains polymères comportent des chaînes macromoléculaires formées de parties chimiquement bien distinctes : soit de longues séquences d'unités monomères différentes, soit encore un grand nombre de chaînes courtes greffées le long du squelette macromoléculaire principal. Lorsque ces parties sont capables de faire montre d'une indépendance mutuelle suffisante, elles se séparent dans l'espace, au sein de petits domaines souvent périodiquement juxtaposés les uns aux autres. Dans ce dernier cas, on obtient des édifices bien organisés, pouvant être comparés aux stases mésomorphes.

Abstract. - Amphipathic copolymers may be obtained in two ways : (a) alternation of two chemical sequences along the polymeric chain; (b) fixation of lateral chains on a macromolecular backbone. When these parts are relatively independent, they tend to segregate in small domains; the domains often build up periodic arrangements, some of which are comparable to the mesomorphic phases.

\section{STRUCTURE DES PHASES PRÉSENTES DANS LES SYSTẼMES LIPIDE-EAU}

\author{
V. LUZZATI, T. GULIK-KRZYWICKI et A. TARDIEU
}

Centre de Génétique Moléculaire du C. N. R. S., Gif-sur-Yvette

Résumé. - L'étude par diffraction des rayons $\mathrm{X}$ de nombreux systèmes lipide-eau a mis en évidence un grand nombre de phases, dont la structure a pu être établie. Le domaine d'existence de ces phases dépend de la nature du lipide (dont le choix s'étend de composés chimiques purs, tels les savons saturés, jusqu'aux mélanges très hétérogènes extraits d'organites cellulaires), de la teneur en eau et de la température. On peut examiner différents aspects de la structure de ces phases :

a) Conformation à courte échelle. Les chaînes paraffiniques peuvent adopter différentes conformations : totalement ordonnée, comme dans les cristaux de savon; très désordonnée, analogue à celle du caoutchouc partiellement étiré ; partiellement ordonnée, avec les chaînes soit étirées soit enroulées en hélice, organisées selon des réseaux à deux dimensions avec désordre rotationnel.

b) Organisation à grande échelle. L'organisation peut être périodique à zéro, une, deux ou trois dimensions. Le premier cas correspond à l'état liquide; le second aux stases smectiques, à structure lamellaire ; le quatrième à l'état cristallin. Le troisième cas (périodique à deux dimensions) satisfait la définition de Friedel d'organisation mésomorphe, mais présente un degré d'ordre plus élevé que celui des stases smectique et nématique.

c) Forme des éléments de structure. Les éléments de structure, c'est-à-dire les régions occupées respectivement par les parties paraffiniques et par les parties polaires, adoptent des formes différentes, qui peuvent être groupées en trois classes : $1^{\circ}$ Lamelles, qui consistent soit de couches planes indéfinies, soit de rubans de largeur finie et de longueur infinie, soit de disques de taille finie. 
$2^{\circ}$ Bâtonnets, soit tiges rigides de longueur infinie, soit bâtonnets de longueur finie, tous identiques, joints trois à trois ou quatre à quatre et formant des filets à deux ou trois dimensions. $3^{\circ}$ Sphères.

d) Distribution des régions polaires et paraffiniques. Dans tous les cas où la structure se prête à une distinction topologique entre régions (" intérieure ) et ( extérieure ) deux types de distributions peuvent exister, selon que les parties paraffiniques occupent les régions ( intérieures ) et les parties polaires les régions (c extérieures ), ou vice-versa. Les deux types de distributions sont observés couramment.

L'ensemble des données expérimentales se prête à des considérations d'ordre chimique, si on envisage la corrélation entre la structure des phases et la nature chimique des lipides, d'ordre cristallographique, si on examine le rôle des éléments de symétrie et l'aspect "cristaux-liquides ) de ces structures, et d'ordre thermodynamique, si on s'intéresse à la nature des forces responsables de la stabilité des différentes structures et du polymorphisme.

Abstract. - X-ray scattering data on lipid water systems display a number of phases; the structure of these phases has been established. The phase diagram depends on the nature of the lipid (pure chemical compounds such as the soaps, or heterogeneous mixtures extracted from cellular organites), on the water content and on temperature. The following features are reviewed :

a) small scale conformation of the paraffine chains : this may be completely ordered (e. g. pure soap crystals), completely disordered (rubber like), or partially ordered (stretched chains or helical chains in a two-dimensional organisation with rotational disorder) ;

b) large scale organization: this corresponds to periodicity in zero, one, two, or three dimensions. The first case is found with liquids, the second with lamellar phases (smectics), the fourth with crystals. The third case (periodicity in 2 dimensions) is mesomorphic in the Friedel sense, but is more highly ordered than smectics or nematics.

c) shape of the structural units, i. e. of the paraffinic and polar regions. One finds three classes :

1) lamellae (indefinite plane layers), ribbons (of indefinite length), discs;

2) rods of infinite length, or jointed rods associated in two-dimensional (or three-dimensional) networks;

3) spheres ;

d) distribution of the polar and paraffinic regions. In some phases the topology allows for an ( inside ) region, and an " outside » region. This may occur either as " oil in water ) or as (" water in oil $)$.

These data are discussed from three points of view : 1) chemistry (correlation between phase diagram and chemical composition); 2) crystallography (symmetries and relations with liquid crystals) ; 3) thermodynamics (nature of the forces stabilizing the various structures). 